\title{
Unit of Temperature
}

National Cancer Institute

\section{Source}

National Cancer Institute. Unit of Temperature. NCI Thesaurus. Code C44276.

An indication of the type of unit of measure being used to express a temperature. 